The ante-tempus novel: prevention and patienthood in recent speculative fiction

\title{
Benedetta Liorsi
}

Lancaster University

b.liorsi@lancaster.ac.uk

This article introduces a way of conceptualising a new medical subjectivity generated by the drive toward prevention that increasingly organises the discourses and practices of medicine, as well as war, state security and economy. The ante-tempus patient, as I call it, is the subjectivity emerging at a moment in time in which medical advances and interventions are shaping the present according to future needs, in order to face, before time, future threats to human health. Contemporary medicine is shifting towards a practice of 'futurology', which seeks less to cure existing diseases than to prevent their occurrence in the first place, thereby bringing forth narratives of the 'un-happened'. Contemporary science fiction offers a fertile ground for investigating this, as well as the anxieties about mass-medicalisation that result. In relation to a contemporary discourse of prevention, the first part of the article explores the concept of mass-medicalisation and the idea of the exploitation and harvesting of 'health' in neoliberal societies. In the second part, the speculative novel The Unit (Holmqvist, 2009) exemplifies and contextualises the key features of ante-tempus patienthood. This medical subjectivity embodied by the novel's main characters represents the outcome of the attempt to create a medical utopia. In this artificially-achieved reality of medical management and control, biological exploitation, forced medicalisation and self-sacrifice merge with neoliberal ideology, translating the discourse of preventative medicine into dystopian terms.

\section{Keywords:}

ante-tempus patienthood, medical futurology, prevention, science fiction, medicalisation

\section{Disembodied health, embodied illness}

'Your health record saves lives. What? How? Why?' ${ }^{1}$ An NHS information leaflet, on clinical trials and the vital importance of biomedical data collection and sharing, demands your attention and puts you on the spot with an authoritative assertion: your health saves lives. The leaflet then explains the value of your clinical history (what); the ways in which your biomedical records, ensuing from every hospitalisation or contact with a practitioner in a clinic, can positively 
contribute to knowledge and research (how); and a summary of evidence showing how health and treatments have improved since the pioneering start of data collection in the UK in the 1940s (why). However positive, optimistic and informative this discourse of 'health' is, the picture positioned immediately below the headline shifts the focus from health to its opposite: illness.

Representations of three anonymous and featureless individuals occupy the rest of the front page of the leaflet. From these stylised images we can grasp very little about their identities of the people represented; shapes standing for an everyman, an everywoman and an every-elderly person. What is striking, however, is how these images, unrevealing in terms of personal identity, are composed by an uninterrupted list of diseases and disorders - including, 'bladder infections', 'varicose veins', 'bulimia nervosa' - which give forms to these anonymous bodies. These words (re)define the body in terms of diseases; the body becomes more than just a potential carrier of disease: the body is disease, in potentia; the omnipresence of past and future illness is presented as constitutive to it.

Eric Cazdyn argues that, in the age of preventive medicine, '[w] hen cancer might be in all of us, and only some of us are unlucky enough to suffer from it $[\ldots]$ then the very categories of health and illness, benign and malignant, cure and relapse, and perhaps even present and future, become permanently confused'. ${ }^{2}$ Havi Carel too points out that the concepts of health and illness are no longer dichotomous. ${ }^{3}$ As the distinction between health and illness has broken down, the object of Western $^{4}$ medicine has become temporally unlimited. When the future, the realm of the actualised potentiality, comes into the foreground and blends in with the present, illness is unveiled as something not-happened-yet but possible, a risk of the future that is 'a threatening possibility,' as Ulrich Beck puts it, that is 'a fact in abeyance'. ${ }^{5}$ Contemporary medicine develops in relation to, and fostered by, 'a new grammar of illness, risk, experience, and treatment, [a grammar] in which the body is inherently disordered and in which health is no longer the silence of the organs; it is the illness that is silent, often with no symptoms' (Dumit 55). These 'silent' illnesses, which exist already and might or will cease to be silent, have nonetheless increasingly become central in 
medical research, public health interventions and pharmaceutical companies' enterprises. Roy Porter, amongst others, has pointed to the irony of Western societies becoming healthier and healthier and yet increasingly craving medicine; ${ }^{6}$ however, beyond the phenomenon of 'overmedicalization', ${ }^{7}$ I would also argue that medicine has become a future-oriented practice that views us always-already as sufferers, and thus always-already in need of treatment as patients. ${ }^{8}$

How can this new form of patienthood, or medical subjectivity, be understood and defined? I suggest the answer to this question lies in the current trend to instrumentalise data on subjects' health and past and future illnesses, genetic knowledge and family history; ${ }^{9}$ this occurs in the broader context of 'bioeconomic' governance, whereby, as Cazdyn argues, 'control over forms of life serves a primarily economic project' $;{ }^{10}$ and in defining every individual, thanks to the advances in biomedicine and genetics, as a carrier of manifest, pre-symptomatic, or a-symptomatic diseases. ${ }^{11}$ The latter point, the temporal displacement of health and illness, is rationalised through a powerful contemporary discourse that also finds its place in the fields of war, state security and economy, as well as medicine: that of prevention. ${ }^{12}$

This article seeks to introduce my conceptualisation of a new medical subjectivity generated by this drive toward prevention. The ante-tempus patient, as I have called it, is the subjectivity emerging at a moment in time in which medical advances, medical interventions, and medical advertisement are able to construct 'new narrative[s]', as Joseph Dumit puts it in his Drugs for Life. ${ }^{13}$ These narratives tell the potential sufferer about their possible medical condition, reconfigure the individuals' possibilities, and 'place new challenges and goals before [them]'. ${ }^{14}$ The present is gradually shaped according to future needs in order to deal, before time, with future threats to human health. ${ }^{15}$ Contemporary science fiction offers a fertile ground to investigate anxieties about mass-medicalisation, not only as an attempt to cure the present, but also to cure future illnesses in the present. However, the idea of healing as a curing process is challenged as medicine embraces characteristics and directions proper of a practice of 'futurology', which seeks less to cure existing diseases than to prevent their occurrence in the first place. ${ }^{16}$ This brings forth narratives offering 
new ways of understanding and philosophising the encounter with disease, ${ }^{17}$ including narratives of what I call the 'un-happened', in which the yet-to-develop disease is a virtual actuality to deal with before it can occur.

This concept of patienthood 'before time' (ante-tempus) appears not only in the medical reality of the contemporary Western world, but also in its critical exploration by science fiction narratives of the new millennium. In the first part of this article I will explore the controversial idea of fostering health with the intent to export and exploit it, and how fostering and harvesting health has become a contemporary reality, rather than a speculative possibility for a dystopian future. I will then go on, in the second part, to explore the ways in which Ninni Holmqvist's novel, The Unit, ${ }^{18}$ diagnoses the possible consequences of this by presenting a controlled society in which medical and biological exploitation of unproductive citizens is legitimised and accepted by the population. To analyse the birth and development of the ante-tempus patient, and its representation in fiction, I will focus on three points: (1) the dystopian and utopian tropes shaping the structure of this narrative about a medicalised reality; (2) the ambiguous notion of self-sacrifice associated with the ante-tempus patient; and (3) the concepts of health production and health exportation that make the ante-tempus patient the main object of preventive medical intervention but, paradoxically, never the full beneficiary of it.

\section{Prevention and the ante-tempus patient}

My work interrogates the present condition of individuals living in an increasingly medicalised Western society and the response to new developing technologies in the fields of science and medicine. I specifically look at new understanding of subjectivities generated in a context in which modern medicine is, as Porter writes, a 'moving frontier' that, '[w]ith transplant surgery established and human cloning feasible, ... is challenging and changing our notions of what a human being is, of what is to be human. ${ }^{19}$ Moreover, in the current social and biopolitical context of a 
'hypercommodified global mediasphere' ${ }^{20}$ neoliberal governmentality has transformed the biological body into a commodity, a product which has value in the market. In contemporary societies, it is not only the healthy body of the productive worker that generates profit; nor is it merely that illness represents commercial opportunities. Diseases and pathologies yet to manifest whether latent, potential, or identified as 'health risk' ${ }^{21}$ - become possibilities for medical and financial speculation too. Information and biodata on both healthy and ill conditions gain a predominant position in the global market of 'bioeconomics' 22 and make the producer of such information, namely the individual scrutinised by the eye of the state, an exploitable tool for medical knowledge and profit. As Dumit critically claims, 'every aspect of the medical world we encounter is being modulated (not constructed, but adjusted) in accordance with profit motives' ${ }^{23}$ New markets - and future markets - thus become available for patients in the expansion of the futurological scope of medicine; this expansion also translates into an increase in prospective or actual patients who, in turn, contribute to fostering and feeding the market system by producing biodata, as well as by creating demand for treatments.

What is envisaged in the future drastically affects the present. Patients and patients-to-be are likely to become synonymous, as the distinction ceases to be meaningful. When potentiality and actuality merge in the status of this object, the paradigm of ante-tempus patienthood becomes applicable to the entirety of the population, in its present and future existence. As individuals increasingly undergo medical intervention before the need for a cure arises, this patienthood expands to include, in a comprehensive way, every single individual as a medicalised or yet-to-bemedicalised being, receiving treatment for future diseases or health alterations. These individuals are shaped by, and belong to, narratives told in the language of state prevention, of public healthcare, and in the advertisement jargon of pharmaceutical companies.

With the emergence of ante-tempus patienthood, then, medicine is increasingly becoming a future-oriented science, looking at the future of yet-to-occur illness, and striving to turn that potentially-ill future into a future free from illness. The repercussion of this is that the healthy 
present state, which is 'foretold' to become diseased in the future, becomes an object for financial speculation and profit, and for political and medical management and control. What I propose here, through a particular reading of The Unit, is that the novel provides us with a key to reframing the problematic of medical prevention. I suggest that, with the future in the foreground, the target of medicine is not to find a cure, nor to heal the now. The objective becomes, instead, that of seizing control of health and harvesting it in order to envisage (and virtually construct) a disease-less future.

The medical gaze - metonym both for medical observation of pathological and biological mutations, and for medical intervention - cast upon the present can thus be seen as a retrospective gaze actively operating on present humanity in order to meet its future-disclosed needs. Moreover, if the retrospective medical intervention works to control, understand, and manage human biological matter, bodies and data, its implied outcome is that of further complicating the status of 'patient', which, in Porter's view, is an 'x factor in equations dominated by economics, sociology, diagnostic, technology, system analysis and multitude of other reference frames'. ${ }^{24}$ This leads us to a conceptually expanded understanding of patienthood: even as preventative medicine aims to eliminate future patienthood, where the patient is defined as the 'sufferer' of illnesses, it makes patienthood insescapable in the present when the patient is conceived of as the consumer of medical products and services, the producer of biodata and the subject of biopolitical management - in advance of any illness arising. I propose the 'ante-tempus' subjectivity to indicate a patienthood condition that is experienced by individuals not when specific health alterations or illnesses are diagnosed, but when the risk of their manifestation is the element to be treated: the 'projected threat', in Beck's words, becoming a 'concrete one'. ${ }^{25}$ Consequently, these individuals appear not to be undergoing medical treatments necessarily for their own benefit.

The ante-tempus patient not only embodies the condition of patient before the actual need for a traditionally defined patienthood occurs, but often endures medical interventions that are aimed at achieving health for the benefit of (future) others. This can be readily seen in mass- 
vaccination, the expansion of data collection, health trials, and the organisation of medical budgeting, as well as campaigns against smoking, drinking, and obesity, which reflect the shift from present health to future illness. This temporal shift is also the shift from an attention to individual health to the biopolitical management of the population, and from the bounded discipline of medicine to its expansion into the realms of politics, law, and economics. Indeed, Dumit argues that pharmaceutical companies increasingly exploit the concept and virtual reality of risk, to create new patients under the 'media logic by which public health's message of prevention comes to take the form of an imperative to do anything possible to reduce risk', ${ }^{26}$ suggesting that medicine has taken on a 'spectacular' quality. ${ }^{27}$

In a reflective and meta-reflective mode, works of fiction explore these social, economic, and biopolitical trends and share some of their terminology and modus operandi. A number of SF literary and cinematographic texts dealing with the effects of new medical technologies and practices can be considered a 'literalisation of the metaphor' ${ }^{28}$ of mass-medicalisation and its biological and ontological consequences (both on the single individual and on the social collectivity). The dystopian regimes portrayed in speculative narratives like Holmqvist's The Unit, Drew Magary's The End Specialist (2011), Mira Grant's Parasite (2013), Kazuo Ishiguro's Never Let Me Go (2005), Steven Spielberg's film Minority Report (2002) and Michael Winterbottom's film Code 46 (2005), among others, deal with medical, biological, and socio-political prevention. ${ }^{29}$ I see different applications of the 'ante-tempus subjectivity' developing in these narratives. For instance, ante-tempus patients are the socially and genetically constructed members of the unageing population told in Magary's dystopian novel The End Specialist; the genetically-concocted and controlled humanity of the border-obsessed global society of Winterbottom's film Code 46; the organ-donor 'students' in Ishiguro's Never Let Me Go, in which society is pre-emptively treated via the invasive and yet implicit medicalisation of the clones; and in the metonymical Washington D.C. citizenry of Spielberg's Minority Report. In the latter, the population, as ante-tempus patients, wait 
for the future to be forecast and revealed, and for its risky factors to be eliminated in advance extracted from the social body by the punitive state.

By approaching the issue of prospective patienthood from this provoking angle, I question the direct connection between the idea of illness and the concept of patienthood, and thus the link that ontologically positions the patient as someone suffering from an illness. ${ }^{30}$ My analysis focuses on a subjectivity that, in its phenomenology, echoes Carel's view on the sufferer experiencing a new 'way of being' in illness. ${ }^{31}$ However, different from Carel's approach, the subject I consider, the ante-tempus patient, is not necessarily constructed by the concrete illness and its social, emotional, physical, and psychological consequences, but by the concretisation, in a narrative or fiction of the future, of the risk of illness.

Illness shapes the role of the ante-tempus patient in a preventative way, as if it were a fictional construct, envisioning the individual under the medical gaze as a possible host for innumerable maladies. The development into this new subjectivity retraces what Carel calls epoché in relation to illness and to the medicalised future of the diseased body. The philosopher's take on Husserl's term describes epoché as 'the bracketing of the natural attitude' - the bracketing of an healthy state that does not imply 'a removal from the world but a shift in a way of being in the world that enables philosophical reflection, without ceasing to take part in the world' ${ }^{32}$ The illness as epoché forces itself upon the person, and the philosophical reflection assumes the characteristic of a re-examination of the ill person's 'bodily habits, existential expectations, experience of the body, space and time, and way of being in the world'. ${ }^{33}$ This forced reflection, as my literary analysis will seek to explain, also appears in the lived experience of a patient before time.

\section{The Unit - diagnosis and treatment of the ante-tempus patient}

From now on it was important that I was kept in good condition and good health in every way. That was the whole point, after all. ${ }^{34}$ 
The necessity to foster health hinted at in the above words, spoken by The Unit's protagonist and narrator attempting to rationalise her treatment, seems to be a core target for contemporary Western medicine's aims. However, if we look at how health has been progressively instrumentalised, and at how illness has become a 'simultaneous' status (as in the case of a-symptomatic or presymptomatic conditions), rather than merely being in opposition to heath, an intricate pattern is revealed. This convergence of health and illness makes it difficult to see the idea of achieving good health as the 'whole point'. In Holmqvist's novel, medicine is no longer simply about the individual's wellbeing; instead, the novel is about managing social wellbeing by exploiting the individual's health in order to 'transfer' it to others. In the novel, 'dispensable' individuals, ${ }^{35}$ redundant for society's growth and wealth, are made into medically exploited subjects displaced from their homes into 'reserve bank unit(s) for biological material ${ }^{36}$ where health is a condition (and a possession) not just to foster, but also to harvest and pre-emptively attack. The dispensable embody the subjectivity of ante-tempus patienthood through which health is seen and experienced as something constructed, overseen in its development and foreseen in its demise.

The fictional context in which the ante-tempus patient exists and undergoes preventative medical interventions develops from a common precedent in the literary dystopian tradition of the twentieth century. In dystopian novels such as We (1924), Brave New World (1932), Nineteen Eighty-Four (1949), and The Handmaid's Tale (1985), the biopolitical control of citizens has always aimed for, in its fictional representations, the ultimate a-legal resolution to objectification, confinement, and exploitation of the population. ${ }^{37}$ These novels present attempts to construct ordered and 'well-functioning' societies, which, nonetheless, result in oppressive expressions of civic, political, and biological dominance. A well-functioning, ordered and healthy society is the utopian dream that soon becomes dystopian from the perspective of the reader and for the novel's protagonist. The latter strives to obtain some form of freedom and performs his or her opposition through actions (like Winston Smith in Nineteen Eighty-Four) or active storytelling (as is the case 
of Offred in The Handmaid's Tale). If the political and social utopia is a paradoxical conundrum and a continuous theoretical and factual work in progress, since the historical utopian fiction of Thomas More (Utopia, 1551) and William Morris (News From Nowhere, 1890), the medical utopia alone presents a more possible, and yet controversial, actualisation, thanks to the continuous advances of science and technology. ${ }^{38}$ However, even if the medical aspect of the utopian project is more achievable and realistic, social and political utopia becomes, as a consequence, pushed even further away from realisation. In Holmqvist's novel, medical utopia is to be attained through individual self-sacrifice, which appears to be democratically assented to and accepted by the population. As the novel reveals in its first few pages and reiterates in its last, what is most disturbing is that this acceptance is complete, challenging the idea of imposed subjugation and victimisation of the exploited by proposing to read the 'dispensable' not as victims, but as indispensable active subjects.

The Unit has been described as presenting us with an 'anti-heroic dystopia' ${ }^{39}$ and a 'haunting' but also 'grotesque' tale ${ }^{40}$ in its earlier reviews. Published within a year of Kazuo Ishiguro's Never Let Me Go (2005), ${ }^{41}$ it retraces the same motif of forced-organ donation, but gives more stress to the elements of biopolitical monitoring and biological exploitation in a medicalised regime. As if opening a bleak window on the life of those called 'dispensable' individuals, the novel narrates the typical experience of a middle-aged person who is understood as not having contributed to the community's development and welfare by creating a household and progeny. The story is set in an unspecified near-future time where the aforementioned 'reserve bank unit(s) for biological material ${ }^{42}$ are allowed to collect people who, according to a policy driven by 'economic considerations', ${ }^{43}$ are redundant for society's growth. However, in the context of Cazdyn's understanding of bioeconomics, the exploitation of these redundant social subjects translates into a production of economical value: they become part of the 'economic project' ${ }^{44}$ that controls life in order to serve financial growth. The social and political community of productive and economically 
valuable individuals, benefiting from the dispensable's biopolitical control, turn into depositories of health and thus into producers of wealth in the social world.

The novel's narrative gives only a few impersonal and sparse hints for these so-called 'needed' men and women, individuals healthy and long-lived thanks to the dispensable ones' residency in the units. They live in the society outside the units, a world not clearly defined in its features, but which recalls contemporary Western societies and perhaps the Nordic model of social democracy. Throughout the text, Holmqvist offers just glimpses of what it means to live in a society that accepts the existence of these banks. However, it becomes clear that this practice has been democratically sanctioned, as we are told by one of the unit's inmates; ${ }^{45}$ indeed, it is a national referendum that legitimises the institutionalisation of these units. Provocatively, then, this is a society of voluntarily compliance, and this is something that I address throughout the analysis, reading the novel as both dystopian and as a critique of neoliberalism. The focus of the narrative is cast almost exclusively on those who do not seem to benefit from the democratic state of things, but who are instead the objectified products and usable tools of such a democracy.

Despite the dystopian trope of the 'external and internal exploitation of humanity', ${ }^{46}$ detectable in the forced sacrifice imposed upon the dispensable, the novel could be read as a 'critical utopia', a 'critical dystopia', or an anti-utopia - complicating its classification. ${ }^{47}$ The biological and medical exploitation of men and women within the unit is not presented as an unquestionably oppressive and domineering act. The sacrifice of the exploited is understood to be meaningful because it enables the existence of a safe and disease-free society outside the unit, and this, as the narrator sees it, dignifies the unit's inmates. In this society, health-threatening and deadly conditions are treated by pre-emptively achieving, harvesting, and exporting health (in terms of both medical knowledge and organic spare parts) from the dispensable people.

The 'genre blurring ${ }^{48}$ character of the novel stimulates the reader's understanding of how an arguably good, or perfect world might look if solutions against the threat of illnesses and social 'stillness' (unproductivity) are found. Diseases are in fact managed and cured through the 
exploitation of the biological life of the (social) dispensable, and the social stillness is opposed and resolved by making dispensable, redundant, and thus exportable from the society those individuals unable to build 'new home[s] or 'produce new people'. ${ }^{49}$ The reader can reflect both on 'the terrors of the present' explored by critical dystopias and on those 'provocative and dispensable figures of possible new ways of living' proposed by utopian narratives. ${ }^{50}$ The Unit provides a new take on the 'social dreaming' Lyman Tower Sargent associates with utopia, ${ }^{51}$ where the same dream is made of nightmarish shades while, nonetheless, alluding to provoking, disturbing, and yet accepted outcomes. It is this controversial social agreement that the novel brings forth, staging it in a fictional space of mass-medicalisation, where the ambivalence between the instrumental benefit and the actual benefit of preventive treatments, and the speculative possibilities of biopolitics and bioeconomics, mirror the ambiguous connection between utopian and dystopian narratives.

\section{The managed temporality of the ante-tempus patient}

In The Unit, Dorrit Weger, a childless novelist with no legal companion and a fluctuating and uncertain income, is the first-person narrator accompanying the reader through the door of one of these banks for biological material, away from the health utopia and deep into the medicalised world of preventive intervention, disease management, and health-harvesting. Dorrit enters the eponymous unit on her fiftieth birthday, after being collected from her house, put into a darkwindowed SUV, and permanently severed from any possible future contacts with the community she is leaving behind. ${ }^{52}$ Forced into a form of patienthood, Dorrit will be an inmate of the facility until her medically-managed and induced death. Her life termination will in fact occur after a massive exploitation of her organism through various medical tests and drugs administration, when she eventually completes her role of dispensable in a way reminiscent of Ishiguro's clones: she 'donates' her vital organs. By enduring medical treatment and by being an object of scientific interventions designed to produce health for others' benefit rather than for her own, Dorrit's 
persona becomes a fictional creation of a preventive medical discourse, belonging to, and metonymically embodying, the concept of ante-tempus patienthood.

Dorrit is one among hundreds of dispensable individuals kept in these units. Having been labelled socially redundant, the dispensable become extremely valuable in these facilities, where they are tested and biologically exploited for the sake of present, and especially future, sufferers. Here, the artificial triggering of illnesses proceeds hand in hand with a form of health-harvesting; these processes take place within and upon the body of the unit's residents, performing the role of patients in an anticipated (ante) temporal dimension. The temporality of the patients, made chronic in the continuous illness management and health exportation, is itself a form of confinement that mirrors the spatial entrapment created by the facility's walls. The ante-tempus patients are kept, by these walls and by their condition, in a chronic present, from which the passing of time is excluded. The future is thus left outside.

In the novel, this outside is a spatial location signifying a temporal location: a future time existing and depending on the present time's exploitation and emptying. To tell this story, Holmqvist constructs Dorrit's persona as inhabitant of the present time of ante-tempus patienthood through the unravelling of this four-part novel. The first-person narrator's story-telling moves from a description of the unit in its misleading glamorous façade (Part 1), to the active engagement of Dorrit into the human experiments taking place in the facility (Part 2). The story then covers the development of Dorrit's romantic relationship with another inmate, Johannes, with whom she conceives a baby. This section ends with Dorrit attempting to escape the unit to begin a new life with her unborn child (Part 3). However, interestingly, Dorrit then decides to voluntarily return to the unit - this challenges the idea of her helpless captivity and complicates the dystopian scenario (Part 4).

Three elements hence rise to the surface in the analysis of Holmqvist's narrative: firstly, the ambiguous willingness of both public and inmates to accept the biological exploitation of the dispensable individuals; secondly, a new understanding of the managed present as a time (and 
space) trapped in chronic stillness - echoing neoliberal capitalism's 'eternal present ${ }^{53}$ - in which medical intervention deals with future or potential health complications; and thirdly, the subtle similarity between literal incarceration and the implied confinement of illness created by the medical discourse of prevention. The speculative character of prevention constructs an inescapable status for the citizen. Defined as a sick individual in potentia, or as Nikolas Rose names it, 'somatic individual, ${ }^{54}$ the citizen is re-interpreted, re-written, and self-recognised as an object of medical interest, of the 'direct-to-consumer advertising' that Dumit problematises, ${ }^{55}$ as well as of surveillance, and biopolitical control.

\section{A metonymy for mass-prevention: neoliberal self-sacrifice?}

There is a conceptual and metaphorical superimposition between the fictional representation of the unit and the expressions of increasing mass-medicalisation and interventions of prevention taking place in the non-fictional Western contemporary world. ${ }^{56}$ The facility has a deceptive façade that conceals its real purpose, namely that of creating a framed environment for people considered useless as active members of a 'phantom' perfect society. The unit appears to Dorrit to be a luxurious residence with sports facilities, restaurants, and shops where, according to the words of the centre's director, there is no need 'to worry about your finances again. You have food on your table, a roof over your head, free access to medical care ${ }^{57}$ But the unit is also a place where Dorrit and her peers are constantly observed, biometrically scrutinised and re-shaped as subjects, in a friendly-looking environment in which they become usable and can feel useful. The spectacle of luxury of this health-producing facility creates a deceiving smokescreen for the neoliberal subject to accept 'civil liberties [being] easily set aside in the pursuit of a national moral project' ${ }^{58}$ Dorrit gives voice, in ambiguous ways, to the forms in which this moral project is understood and the ideological social and medical rationality is internalised: 
In here [the unit] I can be myself, on every level, completely openly, without being rejected or mocked, and without the risk of not been taken seriously. I am not regarded as odd or as some kind of alien or some troublesome fifth wheel that people don't know what to do with. Here I'm like everybody else. I fit in. I count. And I can afford to go to the doctor and the dentist and even to the hairdresser and the podiatrist, and I can eat and go to the movies and the theater. I have a dignified life here. I am respected. ${ }^{59}$

A sense of quasi-relief can be detected in Dorrit's words, as she recognises the 'enhancement' of her condition as a 'rejected' individual. However, it is not clear how Dorrit, and thus the dispensable individuals in general, positions herself with regard to the world outside the unit's walls. Has she found a new dignity (she is now 'taken seriously' and 'respected') in stepping further away from the society that had marginalised her in the first place and in living among people with the same ineffective lifestyle (according to the rigid standards of the aspiring utopian reality she used to live in)? If so, she is experiencing a mutual, communitarian, and restricted form of respect from her peers. The relief in being able to find the positives (and almost the benefit) in being part of the unit's material reveals itself through the text and especially in Dorrit's personal account. Dorrit's self-justification for submitting to be the unit's material is central to the novel exploration of the ante-tempus patient's neoliberal subjectivity. It certainly resonates with what theorists have extensively noted about the spreading neoliberal ideology expanding from the 1980s into the new millennium. ${ }^{60}$ Jane Elliot, retracing Michel Foucault's argument in discussing the 'suffering agency' of the neoliberal subject, points out how 'neoliberal governmentality functions through a complex system of incentives and disincentives' requiring individuals to 'select between options' that will 'have significant effects in the world'. ${ }^{61}$ The dispensable's sacrifice - read as the acceptance of their biological exploitation - is meaningful for the world, but only if the agency of the sacrificing individual is presented as existing and free. Holmqvist's narrative interestingly proposes this form of sacrifice as dignifying. In the above quotation, the 'dignified' ${ }^{62}$ Dorrit 
recognises her imposed situation as the actualisation of what is best for her, as if the 'understanding of [her] own interest', in Elliot words, had been shaped by such ideology. ${ }^{63}$

My reading of the novel focuses on the woman's transformation from being a socially anonymous member of a world similar to ours, to an organic valuable member of a reality of (health) production and (illness) exploitation. The connection she seems to find within the facility, where she can be both 'herself' and, via organ donation, 'everybody else' ${ }^{64}$ stresses both the possibility of community and a disquieting loss of identity. Indeed, the novel suggests a new collective identity where every body is a fragmented (and perhaps interchangeable) ensemble of biological parts, to be used to test, construct, and harvest exportable health. Considering this welcoming attitude towards the birth of an every-body organic self, the dignity Dorrit feels is not found in her abandoning the outer utopian reality. It results, instead, from her becoming part(s) of that utopian society by contributing to its existence with the valuable raw matter of her organic self, upon which medical intervention is performed and from which usable health is exported.

In echoing the neoliberal discourse of free choice, Dorrit's behaviour also challenges 'the traditional subjugation of the individual at the end of the [dystopian] novel' that, according to Baccolini, is indicative of a critical dystopian narrative. ${ }^{65}$ The novel presents a society that repeatedly proves itself to be something other than a dystopian nightmare, or indeed a new form of dystopia for neoliberal times, especially in its anticlimactic finale, in which Dorrit consciously and willingly submits to being a sacrifice. In this scenario the individual's agency under the medicalised and prevention-driven regime 'remain[s] recognizably agency while becoming indistinguishable from profound domination'. ${ }^{66}$ Dorrit's wilful subjugation must be read, then, within the broader scope of the remoulding of subjectivity by neoliberalism, through interventions not only in the realms of culture, politics and economics, but also of health and social wellbeing.

The novel offers a cross-section of the collective subjectivity that takes shape in the metonymical miniature of a completely medicalised society. In such a society, oriented towards the achievement of a perfectly functioning and productive community, the residents 'live and die so 
that the national product will increase. ${ }^{67}$ The existence of the unit does not simply supply the 'needed' individuals with healthy spare body parts, but works towards the accomplishment of utter control over the human organism's behaviour - both as individual body and as population. As one of the residents states, if a 'single brain-dead body can save the lives of up to eight people', ${ }^{68}$ the massive exploitation made in daily 'scientific humane experiments' ${ }^{69}$ allows for a much more important result. Performed on the still-breathing bodies of the dispensable residents, these procedures do not simply represent the direct means to cure already existing conditions, for example, a diseased organ in need of transplantation. Effectively, they enable countless scientific therapies to be tested and medical knowledge to be exponentially gained. As a 'bank', the unit stores wealth in the form of health for those who can afford it, but it is also part of the mechanism fostering the idea of a perfect world where research aimed to enhance the human condition is developed. The perfect world, however, produces a social and medical contradiction: biomedical research improves lives in a safe way for someone only because the physical and conceptual separation between dispensable and needed has been made. In the world of The Unit, medical experimentation and failures (or complications) do not affect those who can or will benefit from health enhancement and cures, almost staging a fictional response and critical solution to the case of clinical trials and to what Dumit calls the "paradox of prevention" ${ }^{, 70}$ - that is, the tendency for many patients to undergo treatment and treatment's (side) effects to prevent the occurrence of illness in only a small number of unlucky individuals. This fictionalisation takes shape in the realist allegory of this science fiction novel, in which the medical eye and the medical hand operate continuously, not on the socially productive needed individuals, but on the dispensable ones.

\section{Health production, management, and exportation: what remains?}

The unit is a metaphorical magnetic centre, a black hole into which health disappears and from which, through exercising the latest technologies, it is produced again and eventually 'released', 
disposed of elsewhere. In the unit all illnesses are gathered and stimulated in order to test treatments, find cures, and produce health to export. Roberto Esposito reminds us that the immunity reaction of the human body acting upon itself happens when, and because, '[the human body] contains an element of the same substance it is intended to defend against' ${ }^{71}$ Esposito sees such a substance as the 'evil' to be 'thwarted' not 'by keeping it at a distance from one's borders' but instead by including it 'inside'. ${ }^{72}$ The immunitas paradigm, with its 'spatial' implications, explored by Esposito, finds critical application in the unit's existence and rationale and further challenges the concepts of illness and health. The facility is effectively meant to 'contain' what is harmful for the rest of society, but it also recreates, within itself, what society needs to be defended against. The residents become being-towards-illness, in a re-conceptualisation of Heidegger's being-towardsdeath.

In response to the phenomenological impossibility of treating death as an embodied fact that can be understood as an experience of the human being, Heidegger looks at the becoming of the individual drawn towards that destination (or non-destination) which is the end, the "obliteration' ${ }^{, 3}$ generated by 'something impending, 74 and unavoidable. The 'destining' tension and the sense of inevitability that Heidegger finds in his classification of individuals as 'beings-towards-death' is critically read and challenged by Carel in her phenomenological study of illness. She especially stresses the necessity to associate the 'being-able-to' feature of the human being, whose 'present actions have meaning in virtue of being part of a project [of becoming] that is forward-looking, futural', with the 'inability-to-be' of the ill person, who nonetheless still 'lives' and 'becomes' in the $_{\text {world. }}{ }^{75}$

My analysis engages with Heidegger's nomenclature of the individual who expands and moves towards something that cannot be fully experienced, and Carel's insight of illness as both a way of being and a powerful defining character of an evolving subjectivity (of the patient, of the sufferer). What I propose is to think about the 'future illness', the 'pending' health risk of worsening conditions, and the necessity to prevent, all as constitutive of the 'forward-looking' 
project that defines the contemporary individual in neoliberal capitalist society. Currently, when scientific and technological advances enable medicine to work on the prevention of diseases' manifestation, what 'stands before us ${ }^{96}$ is not (just) death, but indeed a progressively exhaustive picturing of potential and future illnesses. In the beings-toward-illness is the lived experience of the ill that turns from a 'way of being', as Carel calls it, ${ }^{77}$ into a constant quest for what has not manifested yet, something existing in a future time to be, nonetheless, foretold and anticipated.

In Holmqvist's novel the residents are women and men whose meaning and identity are shaped by the impending idea of possible illnesses that can, or will, manifest in the future. They are turned into ante-tempus patients to prevent biological decay from happening. Naming these exploited individuals 'patients' can be problematic and contradictory; however, although the unit's residents do not benefit from the medical intervention performed upon them, they are treated by medical personnel as carriers of biological material that is turned into future and dispensable health.

The residents are thus carriers of health, as well as carriers of illness, fictional personae disquietingly reminiscent of the nameless NHS silhouettes mentioned in the first part of the article. The relation between the residents and health is a complex one that complicates the understanding of the residents as lab subjects stripped of their human and social connotations. The ante-tempus patient, although deemed to never be healthy for his or her own sake, is still ontologically bound to the essence of 'health' and to the awareness of a societal body in need of cure and medical aid. As mentioned above, Dorrit, in joining the unit, comments upon the attention she would expect to experience as a resident, acknowledging that '[f]rom now on it [is] important that I [am] kept in good condition and good health in every way. That [is] the whole point, after all' ${ }^{78}$ The "whole point' does not solely refer to Dorrit's necessity to be kept in good health by the unit's management. The above statement instead introduces her understanding of the resident's role (as ante-tempus patient) and of her ambiguous bond with health. She acknowledges her belonging to a sort of patienthood. The 'whole point' of the residency is in fact to be kept under medical control and to live the existence of an actual patient, who endures the medical gaze and who is kept in a 
'condition' that is good because exploitable, but which is not translatable into these patients' wellbeing.

To solve the ambiguity of the conceptualisation of (ante-tempus) patients as individuals who are not cured for their own health, but who are treated to obtain $a$ usable and exploitable health, the concept of 'health' becomes charged with a double meaning. The understanding of health changes according to whether it is experienced or simply carried. Dorrit steps into the patient role in advance when she is still in 'good condition' and in 'good health'; however, she will not be able to experience health, but she will simply allow its harvesting, preservation, and eventual exploitation. The phrase 'to be kept in good health' is easily read as the bleaker 'to be kept as a source of good health'. In this way the dispensable women and men are taking over and bringing to its exhaustion and completion the role of the ante-tempus patient; a role constructed by the need to preserve health, to deal with diseases not manifested yet, but already envisaged in their future manifestation, and to make health a manipulable object for biopower and bioeconomy.

Being patients before time, the residents lead their existence in a medicalised and overcontrolled reality where they are tested and made ill through experimental drugs, all sorts of new antidepressants, and multi-purposed hormone dosages in order to find cutting-edge therapies. ${ }^{79}$ This reality seems to be mimicking and bringing to its extreme the managed 'crisis' that Cazdyn, in The Already Dead, associates with the Western contemporary world. As part of the theorization on global capitalism and socio-political international dynamics, Cazdyn offers an analysis of this medicalised world in which priorities have shifted and health is not the end anymore, but the means. The end appears to be illness management, and thus the 'quest for health' becomes the intermediate process to obtain such a management. Health is also the means to make profit, and a tool to trigger and maintain medical and social management and control over the population. Cazdyn points out how today 'categories of cure and management cannot be separated', ${ }^{80}$ challenging the current understanding of the outcome of the healing process. In fact, if paradoxically and provokingly the 
management of the diseased condition is preferred to its eradication, the healthy status becomes considerably affected.

Following this thought, and drawing from Holmqvist's narrative, we see a strengthened connection between the definition of the ante-tempus patients and that of beings-towards-illness, as we deduce that the ultimate destination of health and of the healthy individual is, paradoxically, illness. It is with illness as propulsive drive that medical discourses are shaping reality and affecting our understanding of the difference between what is healthy, ill, potentially-healthy and potentiallyill. The production of health is an endless form of harvesting and construction exerted upon patienthood. Dorrit and her peers do not benefit from the cure; health is obtained, then it is taken away, exported, and fully experienced as a disease-free physiological condition only by someone else, in the chronologically and physically displaced outside.

If we challenge a simplistic interpretation of the novel that positions Dorrit and her fellow inmates as guinea pigs in a nightmarish pseudo-medical laboratory, the residents can be seen as embodying men and women enduring the extreme outcome of medical and scientific foresight. Dorrit in fact lives in an apparently safe and pristine space that exists in response to a (medical) gaze into the future; this is a gaze that attempts to forecast diseases and triggers pre-emptive action in order to gain and foster health in the present. The woman, as dispensable and ante-tempus patient, epitomises the biological ground where the constant and never-ending (chronic) process of acting ahead of time to fix expressions of sickness happens, and where present and future, in Cazdyn's words become 'permanently confused' ${ }^{81}$ In this context of a biopolitical 'safeguarding' of the individual, the sine qua non element is, however, the constant biomedical monitoring and the biologically exploitable organism to be made always and willingly available. The character of Dorrit, throughout the fictional narrative, develops the willingness to undergo biological exploitation for the sake of future health. As such, the novel forces us to question the extent to which we have accepted and allowed this form of ante-tempus patienthood to begin permeating our lives as well as our literary and cinematic imagination. 
This article has looked at preventive tendencies in the contemporary medical present, in which the increasing "transformation of human conditions into medical problems ${ }^{, 82}$ has led to the gradual development of the ante-tempus patient subjectivity. This social, economic, and (bio)political paradigm finds its fictional representation in speculative fiction, particularly through metaphorical and metonymical dystopian narratives. The Unit embraces dystopian tropes, but also brings forth something new. In questioning a neoliberal ideology that promotes a moral, productive, and useful existence, the story of the 'dispensable' citizens opens up a new fluidness for the dystopian narrative. The biological exploitation of unfortunate characters suggests a less straightforward narrative than expected, centred on the ambiguity of Dorrit's voluntary participation in this biopolitical and medicalised regime. Dorrit's acquiescence disturbingly relates her to the non-fictional self of the contemporary reader, experiencing on their own body the tendency to prevent health risks otherwise affecting the social body. The novel problematises the tendency, both in fiction and non-fiction, to view preventative medical intervention as imperative - as necessary and as a command. ${ }^{83}$ 


\section{Endnotes}

${ }^{1}$ See the National Institute for Health Research website http://www.nihr.ac.uk/documents/about-NIHR/NIHRPublications/NIHR-Patient-Health-Records-leaflet.pdf. [Date Accessed: 10 July 2015]

${ }^{2}$ Eric Cazdyn, The Already Dead (Durham and London: Duke University Press, 2012), p. 19.

${ }^{3}$ Havi Carel, Illness (Stocksfield: Acumen, 2008), p. 77.

${ }^{4}$ Although I recognise the existence and cultural relevance of forms of medicine other than the Western one, I want to develop my analysis from the cultural and geopolitical Western reality I live in, choosing the closest avenue to my experience for looking at and speculating upon the future of medicine and of human beings' in their relation to it. I take Roy Porter's point, opening his book The Greatest Benefit to Mankind (London: HarperCollins, 1997) in recognising the importance of a global point of view in studying medicine, but also his justification for devoting 'most attention to what is called "western" medicine, because [it] has developed in ways which have made it uniquely powerful and led it to become uniquely global' (7). Porter also continues by stating that 'there is every reason to expect the medicine of the future to be an outgrowth of the present western medicine, ... or at least a reaction against it' (7).

${ }^{5}$ Ulrich Beck, Risk Society: Towards a New Modernity, trans. Mark Ritter (London: Sage Publication, 1992 ), p. 52.

${ }^{6}$ Porter, p.717.

${ }^{7}$ Peter Conrad, The Medicalization of Society: On the Transformation of Human Conditions into Treatable Disorders (Baltimore: The Johns Hopkins University Press, 2007), p.146.

${ }^{8}$ The word 'patient' has an extensive and cross-disciplinary history. If Foucault's 'modern patient' implies that medical practice is a means to normalise, control, and shape a more or less passive sufferer under the medical gaze, the traditional model of patient proposed by Talcott Parsons (see The System of Modern Societies. Engelwood Cliffs, N.J.: Prentice Hall, 1971) has shifted the focus from the passive medical subject to the pursuit of health for a, nevertheless, still passive patient. Roy Porter $(1985 ; 1997)$ has historicised the term, challenging the negative aura he finds associated to modern medicine and medicalisation by Foucault and Ivan Illich among others (see Porter, 'The Patient's view: Doing Medical History from below', Theory and Society, 14.2 (1985), pp. 175-198, p. 194). Instead, Porter recognises the development, in current times, of a more active role for the sufferer in their health management. Nonetheless, the amount of nomenclature and theorisations (patient as object, patient as client, patient as consumer, potential patient) makes difficult to draft a linear portrait. As Kevin Wildes writes, "[ $t$ ]he role of the patient has become more sophisticated scientifically, creating more and more options for people [...]. The role of the patient has become more complicated and multifaceted' (Kevin WM. Wildes, 'Patients: The Rosetta Stone in the Crisis of Medicine', Cambridge Quarterly of Healthcare Ethics 14 (2005), pp. 168-176, p. 169). My understanding of patienthood stems from a view of the patient as someone cognitively and socially constructed to seek for health treatments even in the anticipation of future (possible or probable) diseases.

${ }^{9}$ On this regard see Catherine Waldby's concept of 'biovalue' in Waldby, 'Stem Cells, Tissue Cultures and the Production of Biovalue', health. An International Journal for the social study of health, illness and Medicine, 6. 3 (2002), pp. 305 - 323; and the 'commodification' of the human organism discussed in Lesley A. Sharp, 'The commodification of the body and its parts', Annual Review of Anthropology, 29 (2000), pp. 287 - 328.

${ }^{10}$ Cazdyn, p. 152.

${ }^{11}$ Sociologist Peter Conrad points out the insurgence of the new medicalised status of the 'potentially ill' or of 'precancer' patients when genetic tests can generate positive findings. See Peter Conrad, 'The Shifting Engines of Medicalization', Journal of Health and Social Behavior, 4.6 (2005), pp. 3 - 14, p. 8.

${ }^{12}$ For texts on military prevention discourses and warfare studies see Thomas M. Nichols' Eve of destruction: The Coming Age of Preventive War (Philadelphia: University of Pennsylvania Press, 2008), Ian Shapiro's Containment Rebuilding a Strategy against Global Terror (Princeton University Press, 2008), and Beck's Risk Society (1992) among others. Regarding the medical panorama, the journal Preventive Medicine (1972 - ) offers a thorough look upon the changing trend of preventative strategies from the early $70 \mathrm{~s}$ until the present. James M. Fries's innovative and provoking concept of 'compression of morbidity' (Fries, 'Aging, Natural Death, and the Compression of Morbidity', The New England Journal of Medicine, 303. 3 (1980), pp. 130-135) also contributes to shaping the social and biopolitical context fostered by the preventative drive.

${ }^{13}$ Joseph Dumit, Drugs for Life (London: Duke University Press, 2012), p.31.

${ }^{14}$ Ibid., p. 31. 
${ }^{15}$ For references to the medical advances in the Western world at the end of the twentieth century see Roger Cooter and John Pickstone, Companion to Medicine in the Twentieth Century (Amsterdam: Harwood Academic Publishers, 2000) and Porter's The Greatest Benefit to Mankind (1997). For a view on the promises of genetics, genomics, and the preventative approach of medicine see Garcia Martinez de Lecea and Rossbach, 'Translational genomics in personalized medicine. Scientific challenges en route to clinical practice', The HUGO Journal, 6 (2012), pp. 2-9. On social healthcare and mass-medicalisation see Conrad (2007).

${ }^{16}$ My understanding of 'futurology' and 'medical futurology' develops from the context outlined by Michael Lee in Knowing our Future: the Startling Case for Futurology (Oxford: Infinite Ideas, 2012). In here Lee cites H. G. Wells' non-fiction work Anticipations (1901) as witnessing that interest and continuing quest in the twentieth and twenty-first centuries to create a science of the future. Shifting the act of foretelling from the realm of the metaphysical to that of the social science, futurology came to be understood as a discipline of 'useful sociological foresight' (Lee 19) and as an attempt to create a usable future. See also Vladimir Yakunin's Problems of Contemporary World Futurology (Newcastle upon Tyne: Cambridge Scholars Publishing, 2011). Medical futurology is a shift from the analysis of present-day societal trends to the scrutiny of the human organicity by means of increasingly advanced technologies that results in 'speculative' narratives of medicine, or in the 'new grammar of risk' that Dumit sees developing in relation to the consumerist society of patients, prospective patients and future patients. To expand on this, see Dumit's Drugs for Life (2012) especially Chapter Two, 'Pharmaceutical Witnessing and Direct-to-Consumer Advertising.'

${ }^{17}$ Consider the role of the phenomenology of illness to question and understand new subjectivities developing in a context of health-alteration explored in Carel's study (Carel 2008). Carel offer a positive key to reading the health narratives generated by the appearance and experience of illness as a way to, after the difficulty of the fear and pain of the diseases, embrace a new living self, and a new life experience. 'Illness is an abrupt, violent way of revealing the intimately bodily nature of our being' (Carel, p. 27); in illness, the body is still a 'lived' (p. 76) and living body.

${ }^{18}$ Ninni Holmqvist, The Unit, trans. Marlaine Delargy (Oxford: Oneworld Publications, [2006] 2010).

${ }^{19}$ Porter, p. 668.

${ }^{20}$ Cazdyn, p. 69.

${ }^{21}$ See Beck (1992).

${ }^{22}$ Cazdyn, p. 152.

${ }^{23}$ Dumit, p. 62-63.

${ }^{24}$ Porter, p. 668.

${ }^{25}$ Beck, p. 52.

${ }^{26}$ Dumit, p. 105.

${ }^{27}$ Guy Debord, The Society of the Spectacle, trans. Ken Knabb (Berkeley: Bureau of Public Secrets, 2014).

${ }^{28}$ Mark Currie, The Unexpected. Narrative Temporality and the Philosophy of Surprise (Edinburgh: Edinburgh University Press, 2015), p.150.

${ }^{29}$ Drew Magary, The End Specialist (London: HarperCollins, 2011), Mira Grant, Parasite

(London: Orbit, 2013), Kazuo Ishiguro, Never Let Me Go (London: Faber and Faber, 2005), Steven Spielberg (dir.), Minority Report (DreamWorks, 2002), Michael Winterbottom (dir.), Code 46 (MGM, 2005).

${ }^{30}$ Carel's phenomenological attention to illness focuses on the embodied illness in the present and its repercussions upon the sufferer as a subjectivity in contrasting opposition to that of the 'healthy'. To expand further on this issue, see Carel's account on the phenomenology of illness and of her illness - LAM, a rare fatal lung diseases (Carel, p. 137) - in which her condition appears repeatedly phrased and stressed as in opposition to that of the 'healthy' (healthy family, friends, acquaintances, others).

${ }^{31}$ Carel, p.67.

${ }^{32}$ Havi Carel, 'The Philosophical Role of Illness', Metaphilosophy, 45.1 (2014), pp. 20 - 40 [Date accessed: 2 October 2016], p. 27.

${ }^{33}$ Ibid., p. 29.

${ }^{34}$ Holmqvist, p. 15 .

${ }^{35}$ Ibid., p. 15.

${ }^{36}$ Ibid., p. 20.

${ }^{37}$ Yevgeny Zamyatin, We, trans. Clarence Brown (London: Penguin Classics, [1924] 1993); Aldous Huxley, Brave New World (Harper Perennial Modern Classics, [1932] 2006); George Orwell, Nineteen Eighty-Four (Penguin Classic, [1948] 2013); Margaret Atwood, The Handmaid's Tale (London: Vintage, [1985] 1996). 
${ }^{38}$ For an insight on the non-fictional utopian understanding of the contemporary and prospective medical project look William B. Shwartz, Life Without Disease. The Pursuit of Medical Utopia (University of California Press, 1998), which reviews the medical achievements up to the turn of the new millennium, and advances future trends in biomedicine and genetics from year 2000 to year 2050.

${ }^{39}$ Fran Bigman, 'Ninni Holmqvist's “The Unit”, Words Without Borders. 2010. <http://wordswithoutborders.org/book-review/ninni-holmqvists-the-unit> 10 September 2014.

${ }^{40}$ Valdes, Marcela. 'Book Review: "The Unit" by Ninni Holmqvist'. The Washington Post, 30 June 2009. <http://www.washingtonpost.com/wpdyn/content/article/2009/06/29/AR2009062903971.html > [Date accessed: 10 September 2014].

${ }^{41}$ Holmqvist published the novel in 2006 with the title Enhet. I make references to the English translation, which only appeared in 2010 .

${ }^{42}$ Ibid., p. 20.

${ }^{43}$ Ibid., p. 201.

${ }^{44}$ Cazdyn, p. 152.

${ }^{45}$ Holmqvist, p. 119.

${ }^{46}$ Tom Moylan, Scraps of the Untainted Sky (Oxford: Westview Press, 2000).

${ }^{47}$ Tom Moylan, Demand the Impossible. Science Fiction and the Utopian Imagination (London: Methuen, 1986 ), p. 36.

${ }^{48}$ Moylan, Scraps of the Untainted Sky, p. 189.

${ }^{49}$ Holmqvist, p. 136.

${ }^{50}$ Moylan, Scraps of the Untainted Sky, p. 199, p.94.

${ }^{51}$ Ibid., p. 88.

${ }^{52}$ Holmqvist, p. 4.

${ }^{53}$ See Fredric Jameson, Postmodernism, or, The Cultural Logic of Late Capitalism (Duke University Press, 1991).

${ }^{54}$ Nikolas Rose, The Politics of Life Itself (Woodstock: Princeton University Press, 2007) p. 134.

${ }^{55}$ See Dumit (2012), Chapter Two.

${ }^{56}$ On mass-medicalisation, on the expansion of the medical market due to an increase of pathologising conditions previously not considered diseases, and on the consequences of these on public health management see Conrad (2007). On the raise of awareness, concern, or fear in potential patients to turn them into health products consumers by acting 'preventively' see Dumit (2012).

${ }^{57}$ Holmqvist, p. 21.

58 Wendy Brown, 'American Nightmare: Neoliberalism, Neoconservatism, and De-Democraticization', Political Theory, 34.6 (2006), pp. 690-714 [Date accessed: 14 October 2015], p. 704.

${ }^{59}$ Holmqvist, p. 162, my italics.

${ }^{60}$ See David Harvey, A Brief History of Neoliberalism, (Oxford: Oxford University Press, 2005); Nikolas Rose, Powers of Freedom: Reframing Political Thought (Cambridge: Cambridge University Press, 1999); and Brown (2006).

${ }^{61}$ Jane Elliot, 'Suffering Agency: Imagining Neoliberal Personhood in North America and Britain', Social Text, 115, 31.2 (2013), pp. 83-101 [Date accessed: 10 November 2013], p. 87.

${ }^{62}$ Holmqvist, p. 162.

${ }^{63}$ Elliot, p. 85.

${ }^{64}$ Holmqvist, p. 162.

${ }^{65}$ Moylan, Scraps of the Untainted Sky, p. 189.

${ }^{66}$ Elliot, p. 89.

${ }^{67}$ Holmqvist, p. 104.

${ }^{68}$ Ibid., p. 105.

${ }^{69}$ Ibid., p. 112.

${ }^{70}$ Dumit, p. 113.

${ }^{71}$ Roberto Esposito, Immunitas. The Protection and Negation of Life, trans. Zakiya Hanafi (Cambridge: Polity Press, 2011), p. 21.

${ }^{72}$ Esposito, p. 8.

${ }^{73}$ Carel 2008, p. 96.

${ }^{74}$ Martin Heidegger, Being and Time, trans. John MacQuarrie and Edward Robinson (London: SCM Press, 1962), p. 294. 
${ }^{75}$ See Carel 2008, pp. 66-67. For a more extensive critique of Heidegger's concept of 'being-towards-death' see Carel's Phenomenology of Illness (Oxford: Oxford University Press, 2016).

${ }^{76}$ Heidegger, p. 294.

${ }^{77}$ Carel 2008, p. 67.

${ }^{78}$ Holmqvist, p. 15 .

${ }^{79}$ Ibid., pp. 66-70, p. 144, p.78.

${ }^{80}$ Cazdyn, p. 59.

${ }^{81}$ Ibid., p. 19.

${ }^{82}$ See Antonio Maturo, 'Medicalization: Current Concept and Future Directions in a Bionic Society', Mens Sana Monographs 10.1 (2012), pp. 122-133 [Date accessed: 12 February 2016], and Conrad (2007).

${ }^{83}$ See Beck (1992), Rose (2007). 